and a large steam-power station is an easily located target. This has led to the construction in several countries of the Continent of bomb-proof stand-by power plants for the essential services in towns or districts or for supplying the power requirements of munition factories. These plants are either of the surface or of the underground type. The plan of a station for an output of $10,000 \mathrm{kw}$. is shown located in a tunnel cut into the face of a cliff. The turbo-set, boiler and tanks containing sufficient fuel for 7-10 days' service, and the auxiliary starting set, are accommodated in a gallery about $150 \mathrm{ft}$. long and of about the section of a normal double-track railway tunnel. When ground conditions are not favourable to such a disposition, or the danger of flooding exists, a station of the surface type is adopted, with roof and walls of reinforced concrete about $4 \mathrm{ft}$. thick, having the appearance of a block of dwelling houses or made inconspicuous in some other way.

\section{A Naturalists' Directory}

WE have recently received a copy of the thirty-first edition of the "Naturalists' Diary" (Salem, Mass., U.S.A. : The Cassino Press. 3 dollars). It contains the names, addresses and special subjects of professional and amateur naturalists of North and South America, etc. This list will prove very useful to naturalists in the United States, since for that country it seems comprehensive; but in other countries, such as Great Britain, its usefulness is impaired by the sparsity of entries. For example, for the State of New York alone there are about four hundred and fifty entries, while for the whole of Great Britain there are only eleven; for France, six and for Germany, six. The list should prove useful, however, to naturalists outside the United States who wish to get in touch with their American contemporaries. Appended to this directory is a short list of scientific periodicals. While in the compilation of such a list it is naturally essential to be selective, it is difficult to understand what policy was adopted by the compilers, since it is rather inconsistent. Most of the periodicals are American ; but even here it is difficult to see why the Journal of Applied Physics should be included in a list for naturalists, and the Botanical Gazette omitted. Again, among the British journals is included the Journal of the Chemical Society, but not the Aquarist and Pondkeeper or Discovery. Of foreign journals, only Scientia and Helvetica Physica Acta are mentioned, whereas journals of international appeal to naturalists, such as Chronica Botanica, are omitted. The price for a paper-covered book of about 230 pages is high.

\section{Periodicals for Medical and Scientific Libraries}

THE selection of periodicals for medical and scientific libraries is discussed by C. C. Barnard, librarian of the London School of Hygiene and Tropical Medicine, in a paper in the Library Association Record of November, 1938. Mr. Barnard gives a comparison of results obtained by Gross and Gross' method of arranging periodicals in order of importance as indicated by the frequency of bibliographical reference to them, taking the Journal of the American Chemical Society for 1927 instead of the 1926 volume as used by Gross and Gross. Although agreement is satisfactory at the top of the scale, there are considerable variations lower down, and Mr. Barnard points out that, besides the inherent limitations of the method, which does not take account of frequency of publication of the periodicals or of the length of their articles, comparison on the basis of one year's references is too narrow to be trustworthy. Results obtained at the London School of Hygiene and Tropical Medicine for a large number of medical periodicals by marking each volume or part on the table before return to the shelves are tabulated and discussed, particularly as a check upon the personal selection of experts. Mr. Barnard directs attention to the infrequent reference to the earlier volumes of even such periodicals as Annales de l'Institut Pasteur and Zeitschrift für Hygiene, and suggests that the compilation of similar records by all libraries co-operating in the inter-library loans system might permit recommendations on the basis of a comprehensive survey which would effect appreciable savings in postage and also in time and labour by the redistribution of certain periodicals among the participants.

\section{ASLIB Conference Report}

THE report of proceedings of the fifteenth Conference of the Association of Special Libraries and Information Bureaux (price 5s.), which has just been issued, contains the text of papers presented at the Conference together with summaries of some of those presented at the joint session with the International Federation for Documentation on the organization of information services. An additional paper from Mr. G. Lightfoot, secretary, Council for Scientific and Industrial Research, Commonwealth of Australia, on the establishment of an information service by that Council is also included, as well as summaries of certain papers contributed to the joint session on 'tools' for library co-operation and reports received from the National Central Library and the British Society for International Bibliography.

\section{Air Raid Precautions in Hospitals}

A воOKLET containing advice on the structural and other precautions that can be taken against air raid risks in hospitals has been issued jointly by the Ministry of Health and the Department of Health for Scotland to all local authorities controlling hospitals and also to voluntary hospitals (London : H.M. Stationery Office. 3d. net). Hospital authorities are urged to proceed at once with the precautions recommended, the extent to which they do so depending in some degree on the likelihood of air attack in the area. Measures are described for the adaptation of existing buildings, as well as structural features suggested for new buildings. The Government is prepared to contribute to the cost of these measures under certain conditions. 